\title{
Resilience skills used by front-line workers to assemble precast concrete structures: an exploratory study
}

\author{
Habilidades de resiliência utilizadas por trabalhadores \\ operacionais na montagem de estruturas pré-moldadas de \\ concreto: um estudo exploratório
}

\section{Guillermina Andrea Peñaloza \\ Carlos Torres Formoso \\ Tarcisio Abreu Saurin}

\begin{abstract}
B

esides increasing productivity, prefabricated building systems can also contribute to the reduction of the levels of risk exposure by workers. However, there are several hazards that can be faced by workers involved in the assembly of prefabricated components, such as being struck by objects during lifting and handling of large components, and falls from height. This paper is focused on the assembly process of precast concrete building systems, widely used in Brazil. It is uses the Resilience Engineering theoretical framework, which has been pointed out as the new paradigm to manage health and safety, being concerned with the abilities of a system to adjust its functioning prior to, during, or following changes and disturbances, so that it can sustain required operations under unexpected conditions. The aim of this paper is to propose guidelines to design preventive measures, based on the identification of resilient skills used by front-line workers involved in the process of assembling precast concrete structures. Those skills were identified in a case study carried out in a construction site in Brazil, in which some critical assembly processes were analyzed at a fine level of detail.
\end{abstract}

Keywords: Precast concrete building systems. Resilience engineering. Resilience skills.

\section{Resumo}

Além de aumentar a produtividade, os sistemas pré-fabricados podem contribuir para a redução dos níveis de exposição ao risco dos trabalhadores. No entanto, existem vários perigos que podem ser enfrentados pelos trabalhadores envolvidos na montagem de componentes pré-fabricados, tais como ser atingido por objetos durante o levantamento e manuseio de grandes peças e cair de grandes alturas. Este artigo está focado no processo de montagem de sistemas de construção em concreto pré-moldado, amplamente utilizados no Brasil. Foi aplicada a abordagem teórica da Engenharia de Resiliência, a qual foi apontada como o novo paradigma para gerenciar a saúde e a segurança, e está preocupada com as habilidades de um sistema para ajustar seu funcionamento antes, durante e após mudanças e distúrbios, e, dessa maneira, sustentar as operações necessárias em condições inesperadas. O objetivo deste trabalho é propor diretrizes para a elaboração de medidas preventivas com base na identificação de habilidades de resiliência utilizadas pelos trabalhadores operacionais envolvidos no processo de montagem de estruturas de concreto pré-moldado. Essas habilidades foram identificadas em um estudo de caso exploratório realizado em um canteiro de obra no Brasil, em que alguns processos de montagem críticos foram analisados em detalhe.

Palavras-chave: Sistemas de construção em concreto pré-moldado. Engenharia de resiliência. Habilidades de resiliência. 


\section{Introduction}

In many work environments, tasks carried out by workers often need to be changed, due to several reasons, such as daily pressures and variable workload; uncertainty and variability between planned and actual work; available resources and information, or awareness of the situation (HOLLNAGEL, 2008). This situation is typical of construction industry. One of the strategies for reducing uncertainty and variability in this sector is the use of industrialized building systems. Besides increasing productivity, those systems also contribute to the reduction of the levels of risk exposure by workers (GAMBATESE; HINZE; HAAS, 1997; GIBB; ISACK, 2003; TOOLE; HERVOL; HALLOWELL, 2006). Neale, Sher and Price (1993) pointed out why prefabricated building systems tend to reduce risk exposure: working methods are often analyzed in detail to improve performance; learning from repetition make work more reliable; and the movement of workers and equipment between tasks can be reduced.

This paper is focused on managing safety in precast concrete building systems, a technology widely used in Brazil. The NBR 9062 standard (ABNT, 2017) defines precast concrete system as an industrialized process, both carried out off-site and then transported to the assembly site, or in temporary installations in construction sites under strict conditions of quality control.

Despite the benefits of precast concrete building systems in the construction industry, some authors have warned for the potential chances of accidents and incidents during the assembly process (GIBB, 1999; FARD et al., 2017). The main hazards faced by workers involved in the assembly of precast concrete components are being struck by objects during lifting and handling of large components, and falls from height (BECKER; FULLEN; TAKACS, 2003; KIRUBAKARAN, 2017; CAMBRAIA; SAURIN; FORMOSO, 2008; FARD et al., 2017).

The literature provides a set of accident preventive measures in the assembly process of precast concrete components:

(a) visit to the site in order to identify local constraints (PINTO, 2004; CAMBRAIA; SAURIN; FORMOSO, 2008; RIBEIRO, 2011; ABNT, 2017; AMRICAN..., 2013);

(b) devise an assembly plan;

(c) properly install the lifting equipment (PINTO, 2004; CAMBRAIA; SAURIN; FORMOSO, 2008; RIBEIRO, 2011; CUNHA, 2011; ABNT, 2017;

\section{OCCUPATIONAL..., 1989; AMERICAN...,} 2013);

(d) isolate the area where the assembly process will be carried out (PINTO, 2004; ABNT, 2017; OCCUPATIONAL..., 1989; AMERICAN..., 2013); and

(e) install collective protection equipment against falls, such as guardrails and lifelines

(CAMBRAIA; SAURIN; FORMOSO, 2008;

ABNT, 2017; AMERICAN..., 2013).

It is worth noting that those preventive measures are mostly focused on technical measures as well as physical barriers. Moreover, it is often suggested in technical and regulatory publications that the tasks should be performed only by skilled and trained workers, although very rarely it is prescribed which kind of skills and qualification the precast concrete assembly team must have (OCCUPATIONAL..., 2002). Overall, traditional approaches to manage health and safety are based on the assumption that safety can be increased by guaranteeing the reliability of the individual system components (humans as well as machines), and that if components or layers of defense do not fail, then accidents will not occur (LEVESON, 2011).

By contrast, a shift on safety management has been proposed in recent years, by adopting a systems approach in which the interactions between human, technology and environment must be understood (DEKKER et al., 2008). Resilience Engineering has been pointed out as the new paradigm to manage health and safety, being concerned with the abilities of a system to adjust its functioning prior to, during, or following changes and disturbances, so that it can sustain required operations under both expected and unexpected conditions (HOLLNAGEL, 2011). In this paradigm, the definition of the process execution method, i.e. how a group of workers actually performs a task, is a critical activity for the success of safety management (Saurin, 2002). As this is time consuming, it is important to identify critical processes that need to be formally planned at a fine level of detail (CAMBRAIA; SAURIN; FORMOSO, 2008).

The aim of this paper is to propose guidelines to design preventive measures, considering the Resilience Engineering paradigm, based on the identification of resilient skills used by front-line workers involved in the process of assembling precast concrete structures. Those skills were identified in a case study carried out in a construction site in Brazil, in which some critical 
assembly processes were analyzed at a fine level of detail.

\section{Safety risks in precast concrete building systems}

Similarly to other industrialized construction technologies, a potential advantage of precast concrete building systems is to create a safer work environment compared to traditional construction technologies, due to several and unexpected conditions (HOLLNAGEL, 2011). In this paradigm, the definition of the process execution method, i.e. how a group of workers actually performs a task, is a critical activity for the success of safety management (SAURIN, 2002). As this is time consuming, it is important to identify critical processes that need to be formally planned at a fine level of detail (CAMBRAIA; SAURIN; FORMOSO, 2008).

The aim of this paper is to propose guidelines to design preventive measures, considering the Resilience Engineering paradigm, based on the identification of resilience skills used by front-line workers involved in the process of assembling precast concrete structures. Those skills were identified in a case study carried out in a construction site in Brazil, in which some critical assembly factors:

(a) the effort involved in controlling risks is reduced, because several tasks are removed from construction sites(GIBB et al., 2004);

(b) site operations become much simpler and more stable, making it easier for workers to become knowledgeable and familiarized with the tasks to be performed on site as well as with the existing risks(GIBB et al., 2004);

(c) the number of tasks performed on ground increases, by eliminating tasks that must be performed at heights, therefore reducing the risk of falls (GIBB; ISACK, 2003; TOOLE; HERVOL; HAALLWELL, 2006);

(d) work can be moved from a confined space to a clear space (GAMBATESE; HINZE; HAAS, 1997);

(e) as prefabrication allows the fabrication process to be moved from the field to a plant, it is possible to use some equipment that can make the work safer and at least partially automated, such as for cutting and welding;

(f) the number of crews involved in the construction site is smaller, reducing the possibility of risks that result from the interdependence between different processes
(POLAT, 2008; MCGRAW..., 2013;

MODULAR..., 2014); and

(g) the construction process becomes faster, reducing the exposure of workers to risks in construction sites (POLAT, 2008; MCGRAW..., 2013; MODULAR..., 2014).

In general, the need for defining preconditions for the assembly of precast concrete building systems is well recognized in the literature, including national and international standards. In fact, some general requirements for assembly plans are provided in some publications, such as the NBR 9062 (ABNT, 2017) in Brazil, OSHS (OCCUPATIONAL..., 2002) in New Zealand and CPPCC (CODE..., 2016) in Hong Kong, some of them attempting to unify safety procedures and codes of practice. However, most of them recognize that it is necessary to prepare detail instructions for assembling each type of component, i.e. the company in charge of the assembly process must devise safety procedures that must be followed in site operations.

\section{Resilience Engineering and performance adjustments}

Traditional safety management theories have been developed mostly for understanding the causes of accidents, with the aim of providing feedback for avoiding future risks. According to Dekker (2006), there is a need to further develop theories and models to improve safety due to the fact that the available tools to predict accidents and to manage organizational safety are ineffective. Based on the Resilience Engineering paradigm, safety assessments of normal work must be made taking into consideration human performance, not in a nominal and standardized way, but rather emphasizing the understanding of performance variability as an expression of the local adjustments humans make in daily work (HOLLNAGEL, 2014). Thus, it is necessary to acknowledge the positive contributions to safety that humans bring to the organization in those situations (MACCHI, 2010).

In the literature, studies in high reliability domains, such as anesthesia (FLETCHER et al., 2002), healthcare (WACHS et al., 2016), aviation (HELMREICH, 2000) and electricity distribution (SAURIN et al., 2014), have analyzed and identified non-technical skills as a way to redesign workplaces, equipment and training programs, so that workers are able to deal with the demands of complex environments. In other domains regarded as risky environments, such as precast concrete building, there is a lack of 
research on the performance adjustments and on the necessary skills for the workforce to cope with unexpected situations.

According to Dekker (2006), organizations need to look at the reasons why people adjust their performance and monitor the adherence to procedures, not simply to enforce compliance, but to understand the gap between prescribed work and practice, and to use that information to redesign both the system and procedures. Hollnagel (2014) proposed three categories of adjustments that can be observed in practice:

(a) to maintain or create conditions that are necessary to do their work or that may be useful in case of future problems;

(b) to compensate for something that is missing or unacceptable conditions, so that it becomes possible to do the work; and

(c) to avoid future problems, i.e. anything that may have negative consequences for each one, a group, or the organization as a whole.

Therefore, adaptability and flexibility of human work is essential for making adjustments to local conditions (HOLLNAGEL; WOODS; LEVESON, 2006).

Saurin et al. (2014) defines performance adjustment as

\section{[...] filling in the gaps of standardized operating procedures whatever their extent and reason, such as under specification for an expected situation or inapplicability for an unexpected situation [...].}

In this study, the concept of resilience skills has been adopted, being defined as "[...] skills of any type necessary to adjust performance in order to maintain safe and efficient operations during both expected and unexpected situations [... $]^{\text {"c }}$ (SAURIN et al., 2014). Those skills are concerned with the observation, analysis, and design of resilience systems (NEMETH; HERRERA, 2015).

\section{Research method}

\section{Research design}

Case study was the research strategy adopted in this investigation. This strategy is preferred when "how" and "why" research questions are being posed, when the researcher has little control over events, and when the focus is on understanding a complex contemporary phenomenon within some real-life context (YIN, 2013). A single exploratory case study was carried out in a university building project, in which a precast concrete structure was assembled by a company that delivers concrete prefabricated building systems.

The main reasons for undertaking this case study were:

(a) this represented an opportunity for collecting data about accidents and incidents in the assembly process of a precast concrete structure in a real construction site, and strategies adopted by the workforce to avoid them; and

(b) the company in charge of the delivery of the precast structure was willing to improve construction methods and safety management, especially in the assembly process.

The research process was divided into four stages:

(a) understanding the existing safety management system and practices adopted by the company;

(b) selection of the critical process to be analyzed, as suggested by Cambraia, Saurin and Formoso (2008);

(c) development and application of a checklist to assess whether the main preventive measures have been implemented before starting the assembly process; and

(d) identification of resilience skills, based on multiple sources of evidence, such as document analysis, interviews and direct observations in the construction site.

Those data sources are similar to the ones normally used to identify critical behaviors in safety studies (FLETCHER et al., 2002).

\section{Description of the company}

The company involved in this investigation is a leading firm in the delivery of precast concrete structures in Brazil. It has more than 1.500 employees and four manufacturing plants. Besides the fabrication of the structural components (beams, slabs, columns, panels), the company also develops the design of prefabricated structures and has assembly teams that carry out site installation. The construction site in which the case study was carried out consisted of a university campus of $55.000 \mathrm{~m}^{2}$. Two thirds of the concrete structure were prefabricated, including four pavements that were built underground. The company was in charge of the design, production and assembly of structural components. The components were produced in a prefabrication plant $450 \mathrm{~km}$ away and transported to the construction site. 


\section{Description of the case study \\ Understanding the existing safety management system}

Three semi-structured interviews were undertaken with the aim to understand the existing safety management system: the site engineer responsible for the construction, the assembly team leader, and the safety technician. Another two interviews were carried out at the company headquarters with representatives from different sectors, such as planning, design, quality and health and safety. All interviews were recorded and lasted on average one hour.

\section{Choice of the critical process}

The choice of critical processes was based on a set of criteria proposed by Dias and Fonseca (1996) and Ribeiro (2011). The first authors pointed out ten categories of processes established by the European Directive 92/57/EEC that need special attention in the safety management in the construction sites. Ribeiro (2011) identified a set of inherent risks in prefabricated construction which require a detail analysis. Based on those two studies, the most critical processes are the ones in which workers are exposed to fall hazards or there is a possibility of being struck or crushed in the construction site (DIAS; FONSECA, 1996; RIBEIRO, 2011). The assembling of precast concrete comprises the unloading of components on site and the erection of those components. In some cases, the storage of a limited number of components is allowed near the area where these will be erected, as long as it does not compromise the required space for maneuvers and operations. An initial meeting with the safety technician and the site manager was held with the aim of identifying the critical processes regarding safety management. Considering the above-mentioned criteria, the process of erecting components was chosen, involving lifting and handling precast concrete columns, beams and slabs.

\section{Development of the safety requirement check-list}

During the analysis of the existing documents at the construction site, the research team realized that the absence of structured list of the requirements for the assembly process caused delays in the project. For that reason, a checklist for verifying the necessary preventive measures to be implemented before the beginning of an assembly operation was jointly devised by the research team and representatives of the company. This checklist was partly based on a literature review about technical requirements for the assembly of concrete structures, e.g. information about turning radius space or maximum slope of ramps. A complete version of the checklist is presented in Figure 1. This checklist was applied before starting the direct observation of some assembly operations.

\section{Identification of resilience skills}

While the analysis of documents (e.g. incident reports) only provide information about the things that went wrong, direct observation provides information about what is going on when things go well and how everyday difficulties were overcome in order to avoid serious problems (FLETCHER $e t$ $a l .$, 2002). Direct observation was focused on the processes of lifting and handling precast concrete columns, beams and slabs. Overall, 30 site visits were made along a period of six months. The visits on average lasted for 3 hours, and data were formally documented in field notes, photographs and video recordings. Several documents were used as references for analyzing resilience skills, including assembly drawings, the proposed checklist for assessing assembly requirements, and existing operational procedures.

Unstructured interviews were usually performed with workforce representatives before and after the direct observation of assembly tasks, with the aim of understanding the decision-making process. Before starting a task, the sequence of operations and the performance expectations were discussed. After task completion, a review was made on the deviations in relation to the planned sequence, and on the decisions that had been taken to effectively accomplish the task. Each interview typically lasted half an hour. 
Figure 1 - Checklist of preventive measures before the assembly of components on site

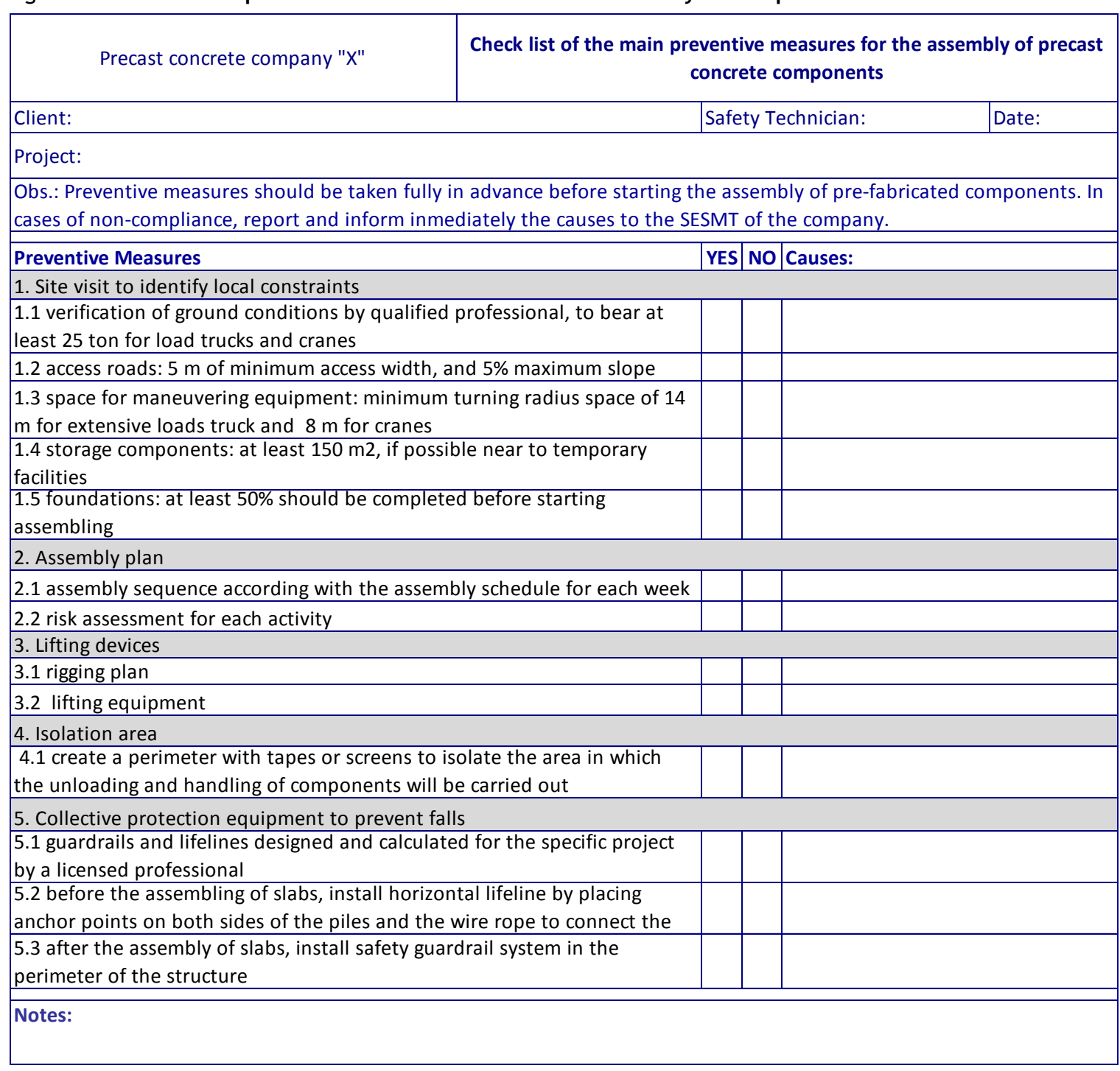

\section{Results}

\section{Overview of the safety management system}

The company uses three main indicators to monitor and measure safety performance, for both manufacturing plants and construction sites: number of lost-time accidents, accident frequency rate, and accident severity rate. The safety staff is hierarchically organized, and for each production unit (plant or site) there is a safety technician in charge of monitoring the crews. In the construction site, focus of this investigation, the safety technician had 6 years of experience in the company. The assembly team consisted of one foreman, responsible for guiding the assembly operation, who had 6 years of experience; one crane operator with 3 years of experience; two assemblers, in charge of handling and installing components, with 4 years and 2 years; and one or two assembly assistants, who had less of 2 years of experience. Two teams were in charge of assembling the precast components in the construction site and the equipment necessary for each team was: a crane, an aerial work platform, and collective protection equipment (lifeline and guardrails). Besides assembling the components, the workers had to handle products for the maintenance and operation of equipment, such as diesel and lubricating oil, guidewires for load orientation, as well as concrete and additives for fixing the joints between components.

Several documents were necessary to start the assembling process: structural drawings, the assembly plan, valid licenses for workers and equipment, and a risk assessment report, among others. In fact, the company had to deal with a 
large amount of documents before starting its operations on site. The company had also developed five operational procedures that contained generic requirements for the assembly process, including responsibilities, reference documents, and the description of unloading, erection and assembly activities for columns, slabs, beams, stairs and panels. Regarding training, assembly team members had to attend a 12-hour expository course which included operational procedures, legal responsibilities, and behavioral and physical education. Learning about safety work practices happened only in the work environment by observing the work of experienced assemblers and interacting with other team members. It is noteworthy that the company did not have a dedicated infrastructure for training in the construction site. The company had weekly safety meetings at its headquarters, but the discussions and decisions were not formally reported. At the construction site, there was a diary for reporting safety problems. However, those reports were only produced when there were problems requiring decisions from top management. Although the company had an incident report system, which is often used for getting insights about the necessary skills for the workforce (FLETCHER et al., 2002), the data available on those events were very scarce.

\section{Analysis of existing preventive measures}

An analysis of the extent of the main preventive measures was carried out according with the proposed checklist. Table 1 presents the number of direct observations of assembly tasks, divided into beams, columns and slabs, and the number of applications of the checklist before assembling components. The checklist was applied 11 times by the safety technician along 30 site visits, since it was applied only once at the beginning of a new task. On average, the level of compliance was $73 \%$. Local constraints, such as access roads, constrained space, and isolation area were items with the lowest level of compliance as shown in Table 1 .

Regarding to first preventive measure- "visit the site to identify local constraints", the site manager performs a sidewalk through the construction site before starting the assembly process, in order to verify the conditions of the ground as well as the access roads and the minimum spaces necessary for component assembly and equipment maneuvering.

Table 1 - Number of observations and number of applications of the checklist

\begin{tabular}{|c|c|c|c|c|}
\hline Operation & Item & $\begin{array}{c}\mathrm{N}^{0} \text { of } \\
\text { observations }\end{array}$ & $\begin{array}{l}\mathrm{N}^{\circ} \text { of applications } \\
\text { of the checklist }\end{array}$ & $\begin{array}{l}\text { Level of compliance } \\
\text { for each item }\end{array}$ \\
\hline \multirow{15}{*}{$\begin{array}{l}\text { Lifting and } \\
\text { handling }\end{array}$} & \multirow{5}{*}{ Beams } & \multirow{5}{*}{ - } & \multirow[t]{5}{*}{ 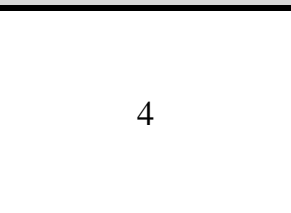 } & 1. $30,0 \%$ \\
\hline & & & & $2.100,0 \%$ \\
\hline & & & & $3.100,0 \%$ \\
\hline & & & & 4. $50,0 \%$ \\
\hline & & & & $5.100,0 \%$ \\
\hline & \multirow{5}{*}{ Columns } & \multirow{5}{*}{6} & \multirow{5}{*}{3} & 1. $80,0 \%$ \\
\hline & & & & 2. $100,0 \%$ \\
\hline & & & & 3. $100,0 \%$ \\
\hline & & & & 4. $33,0 \%$ \\
\hline & & & & $5.100,0 \%$ \\
\hline & \multirow{5}{*}{ Slabs } & \multirow{5}{*}{15} & \multirow{5}{*}{4} & 1. $40,0 \%$ \\
\hline & & & & 2. $100,0 \%$ \\
\hline & & & & 3. $62.5 \%$ \\
\hline & & & & 4. $50,0 \%$ \\
\hline & & & & 5. $45,0 \%$ \\
\hline & Total & 30 & 11 & $73,0 \%$ \\
\hline
\end{tabular}

Note: 1. Site visit for identifying local constraints;

2. Assembly plan;

3. Lifting devices;

4. Isolation areas; and

5. Collective protection equipment to prevent falls. 
A major difficulty related to local constraints was the fact that there were delays in the execution of foundations. In most contracts, the precast concrete company usually requires that $50 \%$ of the foundations should be completed before starting the assembly process. This demand could not be accomplished by the client due to some difficulties faced by the company in charge of the foundations. Considering the pressure to meet the deadline for finishing the project, the precast concrete company accepted starting the assembling with less of $10 \%$ of the foundations concluded. For that reason, there was a substantial overlapping between foundations and the assembly of the concrete structure, creating unexpected constraints, such as performing assembly work in restricted spaces, difficult access to the assembly workstation, and unsuitable soil conditions (e.g. mud) for moving and installing lifting (Figure 2).

The second preventive measure is preparing risk assessments for each activity included in the assembly plan. The assembly sequence was defined by the site manager, and consisted in dividing the project into small batches according to the assembly schedule for each week. Risk assessments were performed by the safety technician every day for each activity to be carried out. Potential risks in the assembly process were identified, documented and communicated to the workforce, making sure that the necessary personal and collective protection equipment were being used in good conditions. Moreover, the necessary equipment and tools were described. Risk assessments were performed only for high risk operations, such as the ones that involve work at height, excavations, electrical services, welding, and operations in very restricted spaces. Although risk assessments were reported to the headquarters, the company did not have the practice to analyze and discuss in greater depth the context specific risks of each project with the workforce in the construction site.

The third preventive measure is concerned with the choice of the lifting devices. It consisted in of devising a rigging plan, which must involve a licensed professional, containing some key information such as crane location, load diagrams, lifting equipment, isolation area as well as dimensions and weights of the components to be assembled.

The third preventive measure is concerned with the choice of the lifting devices. It consisted in of devising a rigging plan, which must involve a licensed professional, containing some key information such as crane location, load diagrams, lifting equipment, isolation area as well as dimensions and weights of the components to be assembled.

The fourth preventive measure was related to the isolation of the area in which the unloading and handling of components would happen, by using some physical components, such as wood guardrails. In most cases, the barriers were properly executed (Figure 3a). There were a few situations in which the isolation of lifting area was inadequate, due to:

(a) the absence or precariousness of the physical barriers; and

(b) difficulties to signal the area in which other activities, such as excavations and foundations, were being executed in parallel (Figure 3b).

Some of these problems were partly caused by pressures to meet the deadlines established in the assembly schedule.

\section{Figure 2 - Unexpected constraints for the assembly process due to overlapping with the execution of} foundations
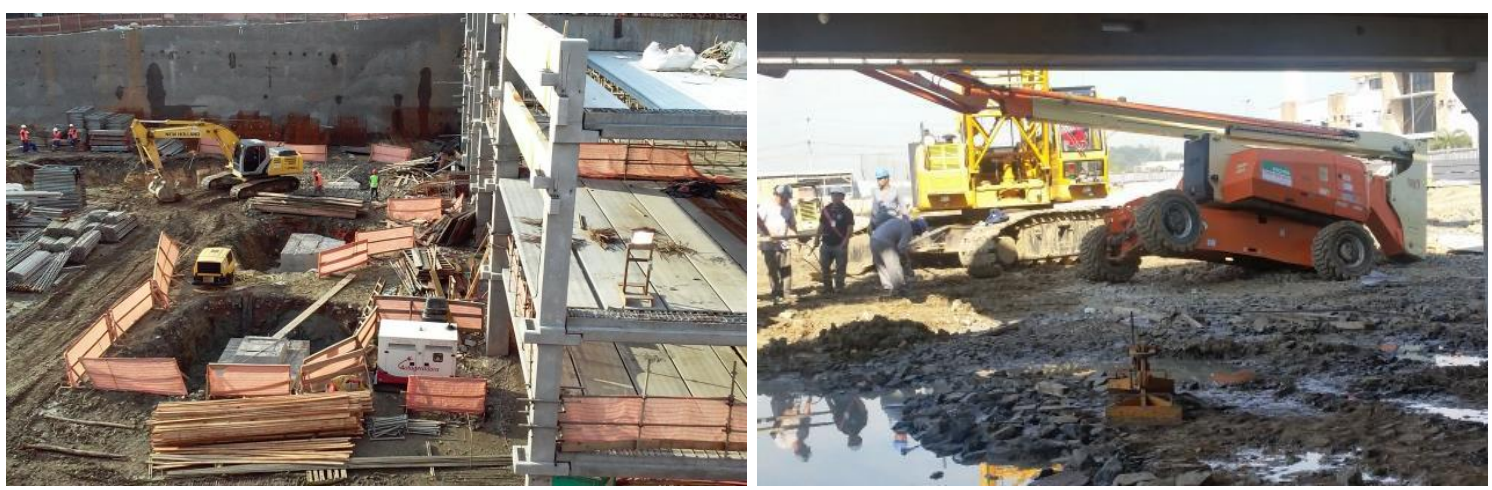

32 Peñaloza, G. A.; Formoso, C. T.; Saurin, T. A. 
Figure 3 - Isolation areas: (a) properly executed and (b) inadequate

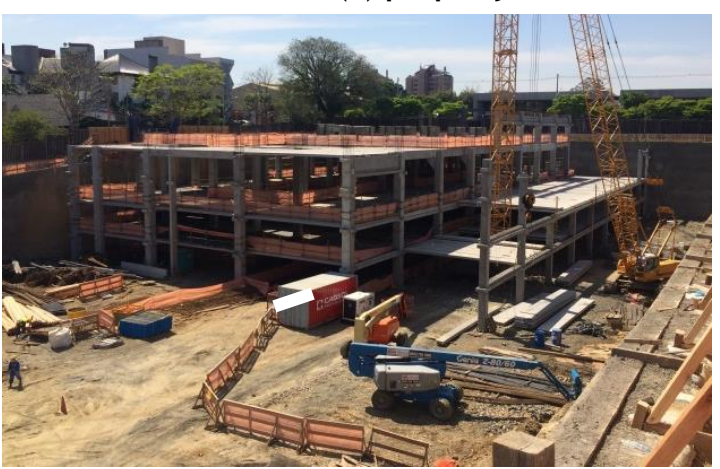

(a)

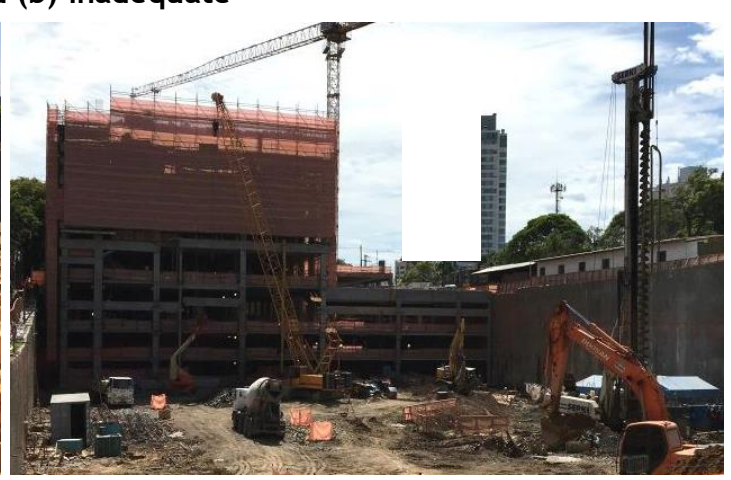

(b)

Figure 4 - Protections against falls: (a) assemblers connected to the horizontal lifeline system; (b) steel safety guardrail system embracing the precast concrete structure

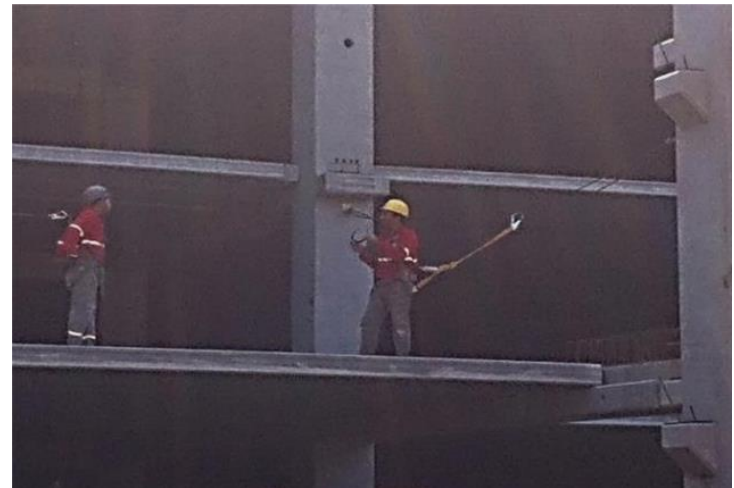

(a)

The fifth preventive measure was the installation of collective protections against falls. Those protections had to be designed by a licensed professional, including guardrails and lifelines for temporary edge protection. After the assembly of beams, workers installed the horizontal lifeline by placing anchor points on both sides of the columns and the wire rope to connect the lanyard safety belt (Figure 4a). After the assembly of slabs, a steel safety guardrail system was placed at the perimeter of the structure. The company normally uses steel guardrails due to the flexibility of the system to embrace the structure without having to pierce the components to fix them (Figure 4b). Although the valid licenses for each crew member to work in the assembly process are always required, little was known about the existing skills and competences, some of them developed in everyday operations. Neither it was known how the assembly crew filled gaps in procedures, and coped with pressures or unexpected situations.

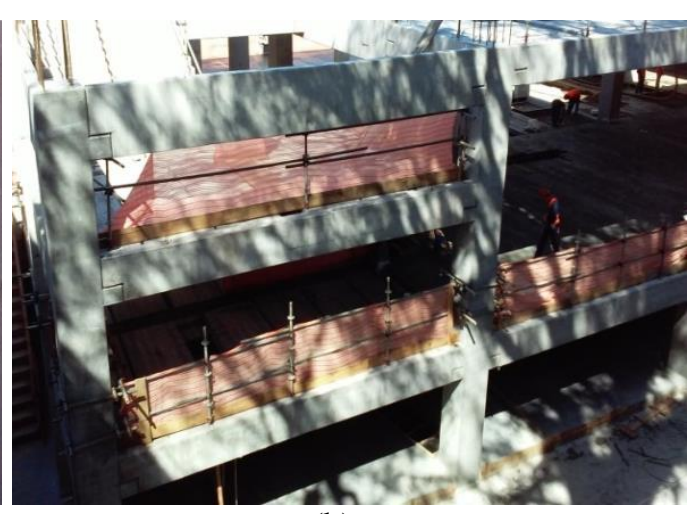

(b)

\section{Identification of resilience skills}

The analysis of the preventive measures as well as the direct observations of site assembly operations and interviews provided an opportunity for identifying performance adjustments from which the resilience skills emerged. It was considered as a potential resilience skill any performance adjustment adopted by front-line workers with the aim to compensate, create conditions or avoid situations, as suggested by Hollnagel (2014). Four categories of resilience skills were identified, as shown in Table 2:

(a) compensate, by discussing set of precise maneuvers in order to reduce risk exposure;

(b) create conditions, by adopting strategies to cope with simple rework;

(c) avoid any rework that brings much uncertainty; and

(d) compensate, by taking an experienced assembler to work at heights. 
Table 2 - Examples of emerging resilience skills

\begin{tabular}{|c|c|c|c|c|c|}
\hline Operation & Item & $\begin{array}{c}\text { Number of } \\
\text { observations }\end{array}$ & Constraints & Resilience skills & $\begin{array}{c}\text { Number of } \\
\text { examples }\end{array}$ \\
\hline \multirow{7}{*}{$\begin{array}{l}\text { Lifting and } \\
\text { handling }\end{array}$} & \multirow[t]{3}{*}{ Beams } & \multirow[t]{3}{*}{9} & $\begin{array}{l}\text { - Limited } \\
\text { space } \\
\text { - Small } \\
\text { storage area } \\
\text { - Lack of } \\
\text { materials }\end{array}$ & $\begin{array}{l}\text { - Compensate, by } \\
\text { discussing set of precise } \\
\text { maneuvers that were } \\
\text { necessary to reduce risk } \\
\text { exposure }\end{array}$ & 3 \\
\hline & & & \multirow[t]{2}{*}{$\begin{array}{l}\text { - design and } \\
\text { quality } \\
\text { failures }\end{array}$} & $\begin{array}{l}\text { - Create conditions, by } \\
\text { adopting strategies to } \\
\text { cope with simple rework }\end{array}$ & 2 \\
\hline & & & & $\begin{array}{l}\text { - Avoid any rework that } \\
\text { brings uncertainty }\end{array}$ & 1 \\
\hline & \multirow[b]{2}{*}{ Columns } & \multirow[b]{2}{*}{6} & $\begin{array}{l}\text { - Design and } \\
\text { quality } \\
\text { failures }\end{array}$ & $\begin{array}{l}\text { - Create conditions by } \\
\text { adopting strategies to } \\
\text { cope with simple rework }\end{array}$ & 2 \\
\hline & & & $\begin{array}{l}\text { - Impossibility } \\
\text { to remove the } \\
\text { lifting pin } \\
\text { from the } \\
\text { column }\end{array}$ & $\begin{array}{l}\text { - Compensate, by taking } \\
\text { an experienced } \\
\text { assembler to work at } \\
\text { heights }\end{array}$ & 1 \\
\hline & \multirow[t]{2}{*}{ Slabs } & \multirow[t]{2}{*}{15} & $\begin{array}{l}\text { - Proximity of } \\
\text { scaffolds } \\
\text { - Limited } \\
\text { space }\end{array}$ & $\begin{array}{l}\text { - Compensate, by } \\
\text { discussing a set of } \\
\text { maneuvers in order to } \\
\text { reduce risk exposure }\end{array}$ & 2 \\
\hline & & & $\begin{array}{l}\text { - Design and } \\
\text { quality } \\
\text { failures }\end{array}$ & $\begin{array}{l}\text { - Create conditions, by } \\
\text { adopting strategies to } \\
\text { cope with simple rework }\end{array}$ & 1 \\
\hline & Total & 30 & & & 12 \\
\hline
\end{tabular}

\section{Lifting and handling beams}

The beams were lifted directly from the truck that transports them or from the ground (storage area) as shown in (Figure 5). Two assemblers place the lifting hooks in the anchor points of the beam and tie a guidewire for handling and load orientation. Figures 6 and 7 show an example of lifting and handling operations, in which the risk of being struck or crushed by components and equipment was one of the major concerns according to the safety technician and assemblers, due to some existing constraints: limited space to maneuver equipment and to handle large beams, and small storage area. In this situation, the assembly team had to compensate for the limited space, by discussing a set of precise maneuvers in order to reduce risk exposure.

Once the beam was lifted and handled to the location defined in the assembly design, two assemblers accessed the installation area by using an aerial work platform and guide the crane operator by hand signals to the correct position. Figure 8 shows three examples in which the assemblers had to assist the fitting of the beam on columns consoles due to design and quality failures such as: beam length was little longer than the span between columns, absence of the column insert pin, and displacement of beam insert holes. In those cases, the main concerns of the safety technician and assemblers were the risks of falls from height, electric shock and fall of components being handled. Figure $8 \mathrm{a}$ illustrates how the assemblers had to create conditions by adopting strategies to cope with simple rework due to design and quality failures. According to the safety technician and assemblers, a simple rework means that they knew what to do, based on past experience. Thus, they decided to sand one face of the beam, while it was being lifted, in order to level it. Similarly, as shown in Figure 8b, during the positioning of the beam, the assemblers realized that the insert pin of the column was missing, and decided to install another pin to ensure the correct attachment. These decisions were made quickly considering the need to reduce risk exposure. Although the decisions lead to an activity with a high level of risk, it was thus executed by the adaptive nature of the work and because there were pressures of term and costs. 
Figure 5 - Lifting of beams
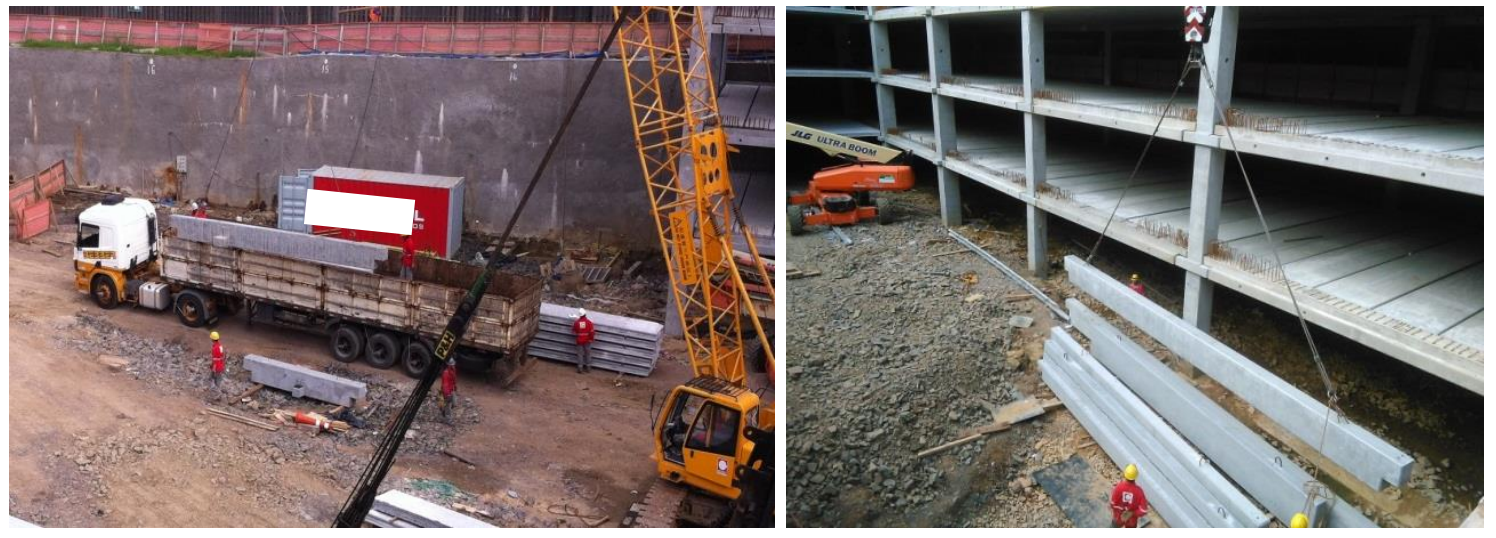

Figure 6 - Restricted space to maneuver equipment and handling components
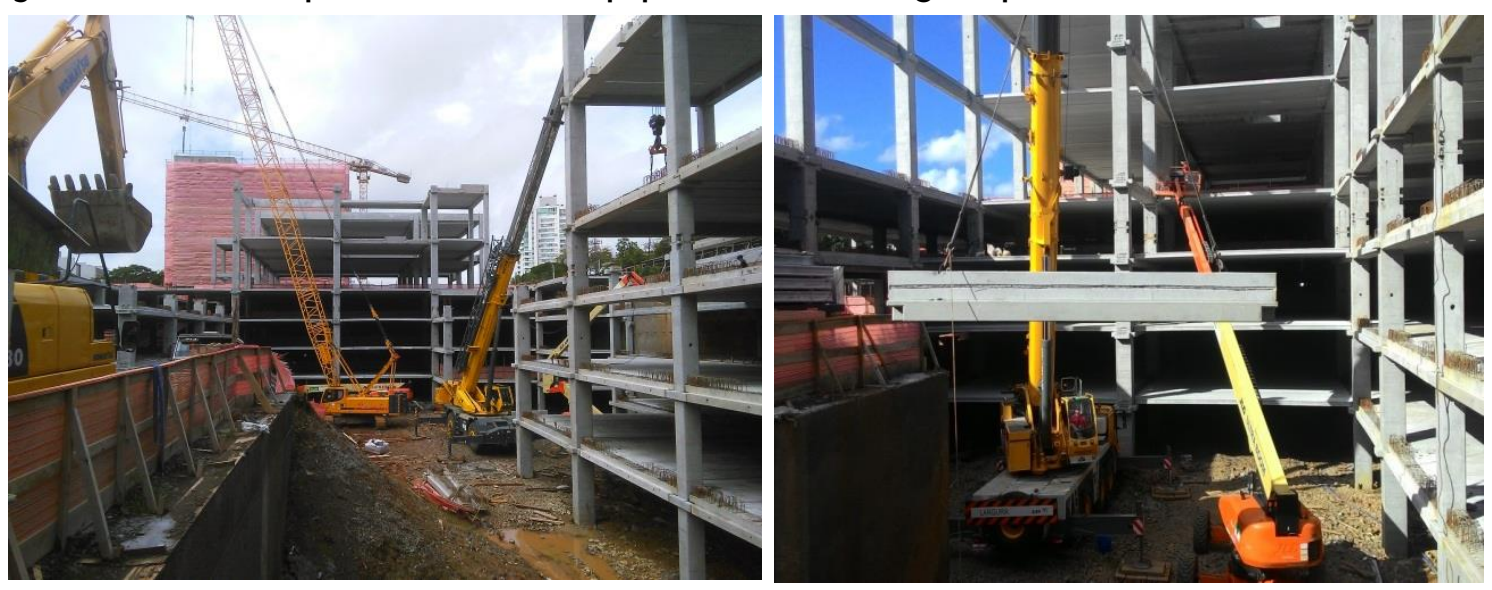

Figure 7 - Assemblers handling the beam in precise maneuvers

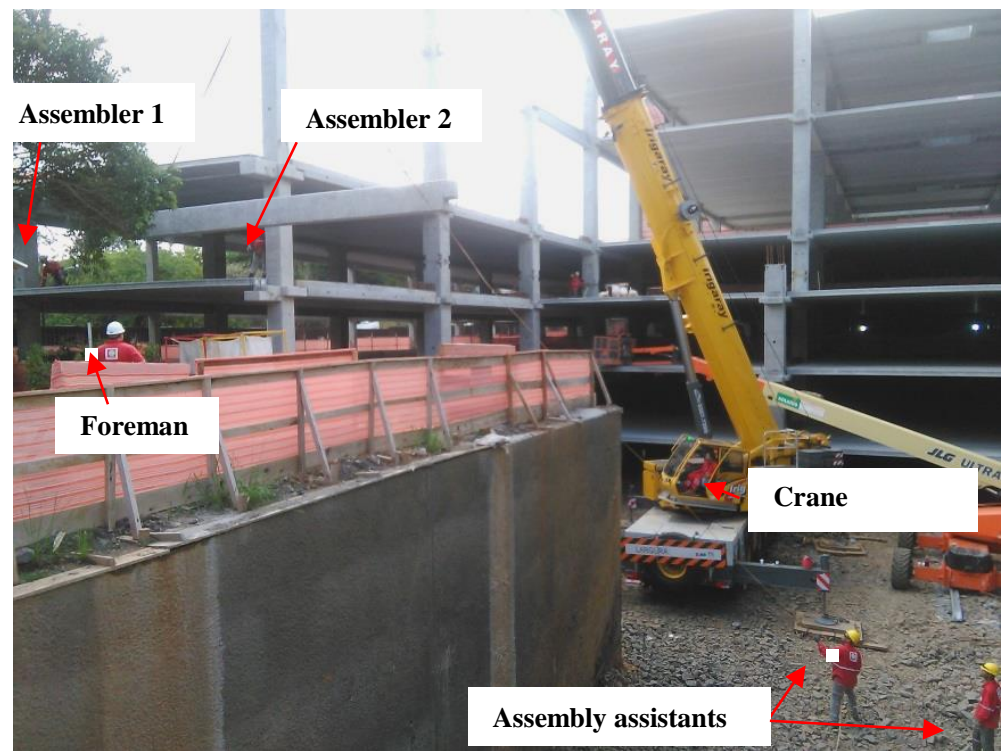

As shown in Figure 8c and 8d, the displacement of the beam holes in relation to the insert pins did not allow the proper positioning of the beam. Due to the complexity of the necessary repairs and the risks involved, the assembly team decided move the beam back to the ground in order to repair the holes according to the beam structural design. As a resilience skill, the team avoided to do any kind of 
rework that had a high level of uncertainty at the workplace due to the risks involved.

\section{Lifting and handling columns}

The columns were lifted directly from the ground, after the assemblers place the lifting pin in the hole of the column. This pin must to be locked to avoid accidental removal, and a rope must be tied on it to aid the removal of the pin after the assembly process, as shown in Figure 9. Once the column is positioned, leveled and plumbed, the assemblers remove the pin from the hole, by pulling the rope tied in the pin lock and then the crane operator down the pulley with the pin attached to the steel cable. This procedure was designed to prevent work at height, but in two cases, due to design and quality failures, the size of the column hole was smaller than the diameter of the pin. The decision made jointly by the safety technician and the assembly team was to bring the column back to the ground, in order to repair the hole and make the necessary finishings, which caused substantial delays in the schedule. Therefore, they decided to create conditions by adopting strategies to cope with simple rework due to design and quality failures, by adapting the diameter of the column hole using an electric hammer (Figure 10).

In one case, after assembling column, an assembler had to help removing the pin using an aerial work platform (Figure 11). This can be considered as a resilience skill: the assembly team had to compensate the difficulty to remove the pin by taking an experienced assembler to do a task with exposure to the risk of falls from height.

Figure 8 - Strategies adopted to cope with design and quality failures: (a) sanding one face of the beam to fit it; (b) Installing a missing insert pin; (c) and (d) displacement of beam insert holes in relation to column insert pin

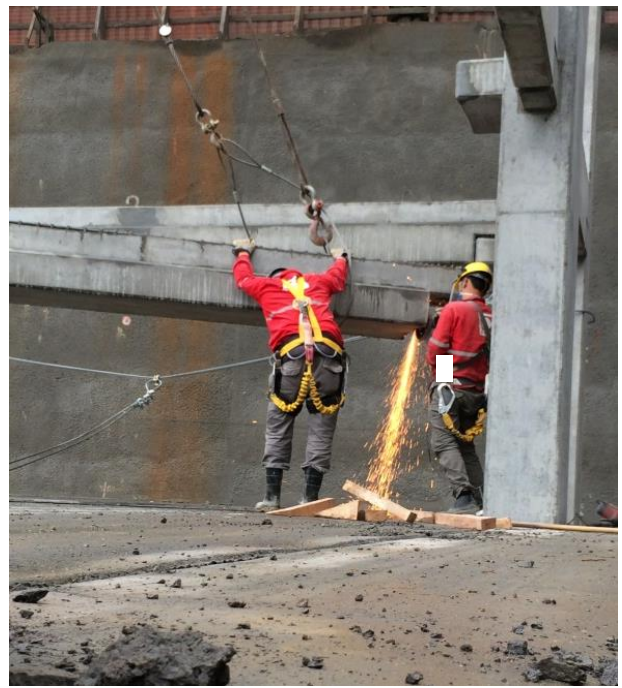

(a)

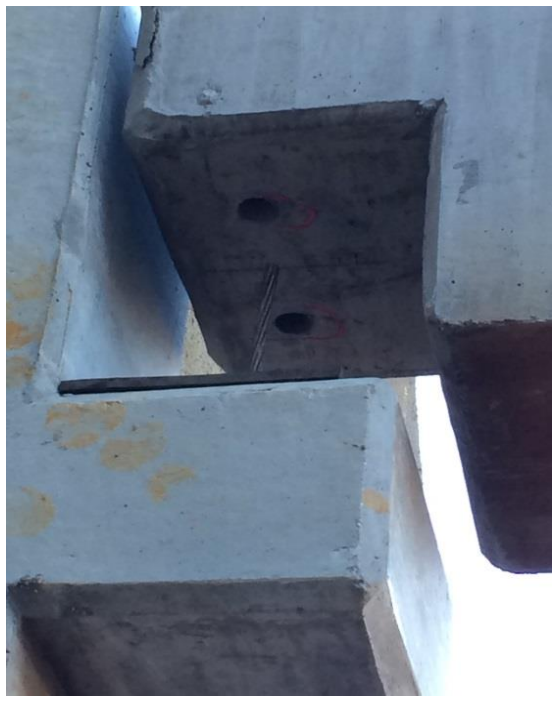

(c)

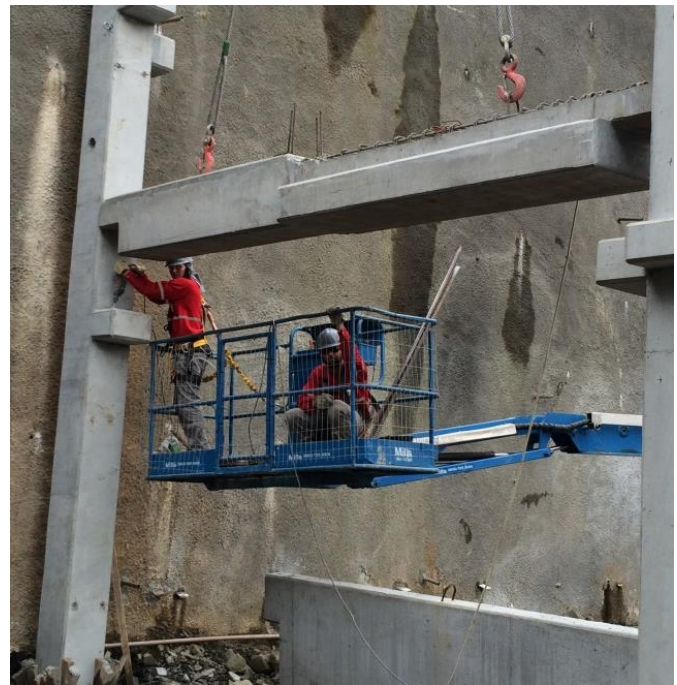

(b)

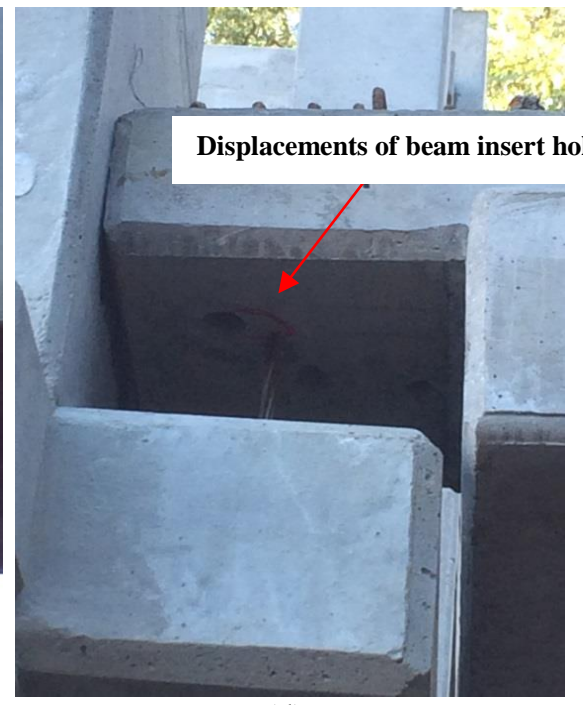

(d) 
Figure 9 - Lifting a column: (a) assemblers placing the lifting pin in the hole of the column; (b) rope tied to pin lock

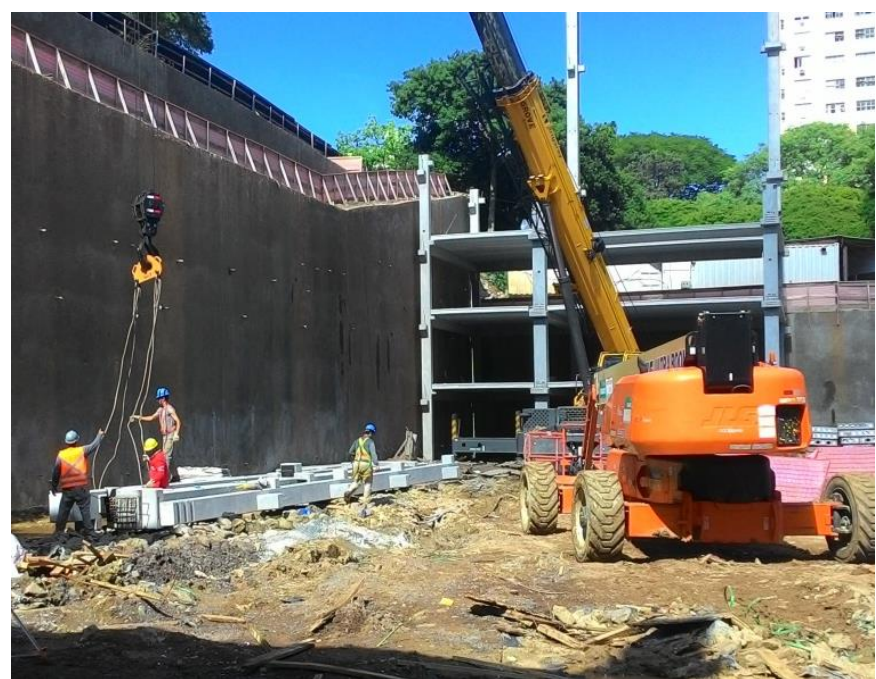

(a)

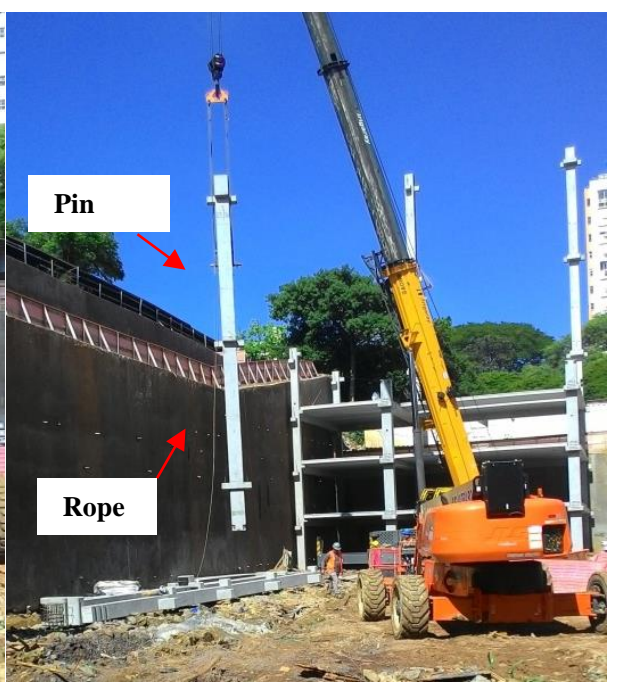

(b)

Figure 10 - Reparing a column: (a) assembler enlarging the column hole; (b) lifting pin placed in the adapted hole

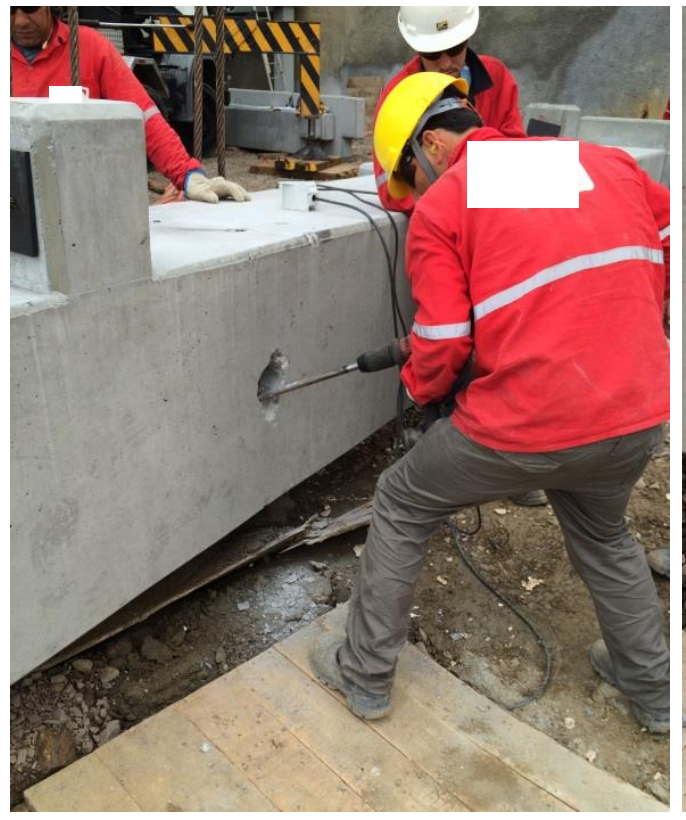

(a)

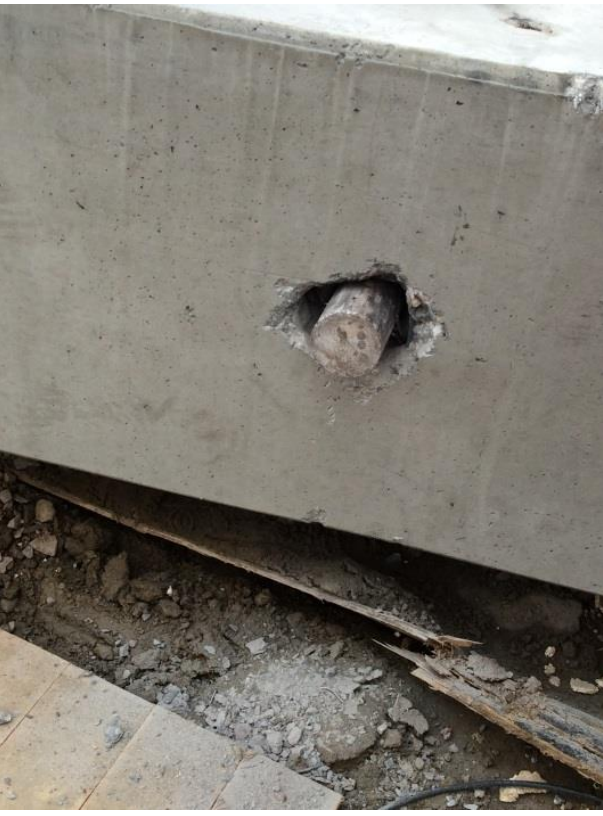

(b) 
Figure 11 - Experienced assembler removing the lifting pin

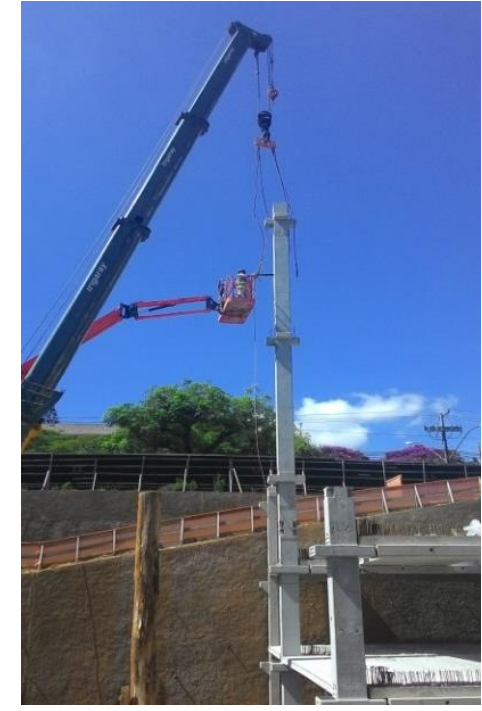

\section{Lifting and handling slabs}

The slabs were lifted directly from the truck or from the ground (storage area), by placing the lifting cable at the ends of the slab and tying a guidewire for handling and load orientation (Figure 12). Then, two assemblers accessed the installation area in order to stand up in a position above the beams, and connected their belts to the lifeline. The assembly assistant guided the slab while the foreman supervised the operation (Figure 13).

One peculiarity of the project was the use of different execution methods. For instance, the underground structure was precast, while some of the floors above ground level were executed in cast-in-situ concrete. Figure 14 shows a situation during the lifting and handling of a slab in which the risk of being struck or crushed by components and equipment was a major concern, due to the proximity of scaffoldings enveloping the in-situ concrete structure, and due to the limited space for maneuvering equipment and handling slabs. Regarding resilience skills, the assembly team had to compensate for the limited space, by discussing a set of precise maneuvers in order to reduce risk exposure. With the aim of preventing the crane lifting devices from colliding with the scaffolds, the assemblers had to coordinate the maneuver of slabs by pushing slowly to the location defined in the assembly design.

Figure 15 shows another situation in which the team assembler had to create suitable conditions by adopting strategies to cope with simple rework, due to design and quality failures. Although the slab label indicates the length specified in design $(10.32 \mathrm{~m})$, the assemblers realized during the assembly operation that the slab was $0.11 \mathrm{~m}$ longer

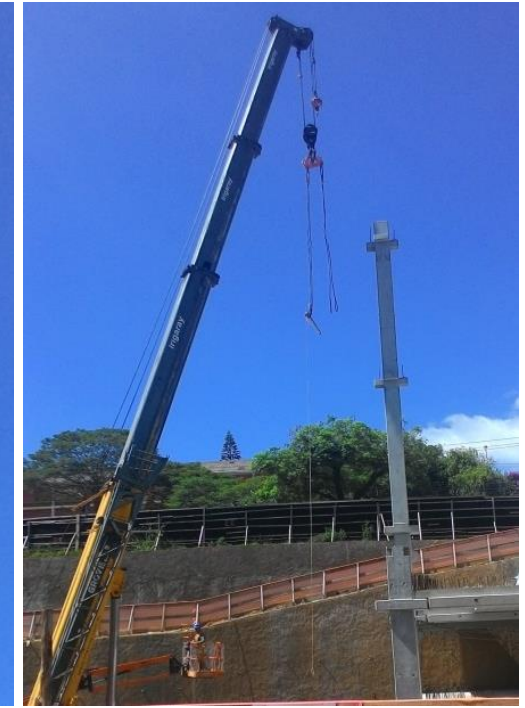

than the length specified. Similarly to the situation that happened with columns, the decision was made to take the slab back to the ground to do the rework, which caused a substantial delay. The site manager, safety technician and the assembly team jointly decided to reduce the length of the slab by using an electric saw (Figure 15b).

\section{Guidelines for the design of preventive measures based on the Resilience Engineering perspective}

Based on the resilience skills identified in the execution of critical precast concrete assembly processes, a set of guidelines to design preventive measures were proposed. These are presented below.

\section{Identify and analyze the context specific risks of each construction site}

The risk assessments adopted by the company became a standardized practice of documenting predefined tasks with higher risks, equipment (including the ones related to safety), and the team responsible for the assembly process. As previously discussed, the lifting and handling of precast concrete components involve several risks, such as falls from height, electric shocks, fall of components, being struck or crushed by components or equipment, among others. However, the scenarios and constraints in which operations are carried out differ from one construction site to another. For instance, the risks involved in the lifting and handling of beams, due to the restricted space (Figure 6), and slabs, due to the proximity of scaffoldings (Figure 14), set specific scenarios and risks which must be

38 Peñaloza, G. A.; Formoso, C. T.; Saurin, T. A. 
considered when planning and discussing preventive measures. Moreover, simple rework in beams, columns and slabs may result in ergonomic risks, such as inappropriate postures and fatigue, which deserve to be analyzed.

An alternative, in this case, could be the use of Building Information Modelling (BIM), particularly 4D simulation models for analyzing physical flows related to the assembly process.
Those models could be used to simulate specific scenarios and to identify potential conflicts and problems, so that adequate preventive measures could be used, improving safety levels during the assembly process. This type of 4D BIM models must be produced at a very detailed level, and need to be updated often, considering the real conditions of the construction site.

Figure 12 - Lifting and handling a slab
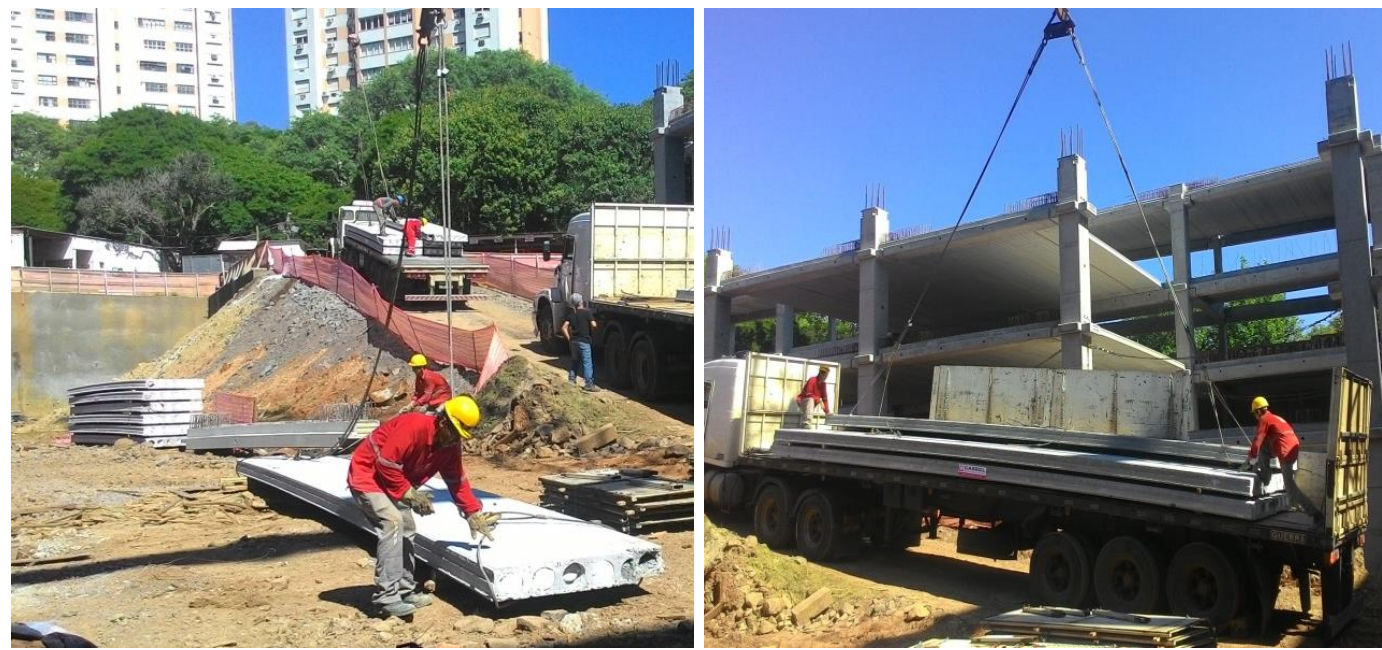

Figure 13 - Assembling a slab

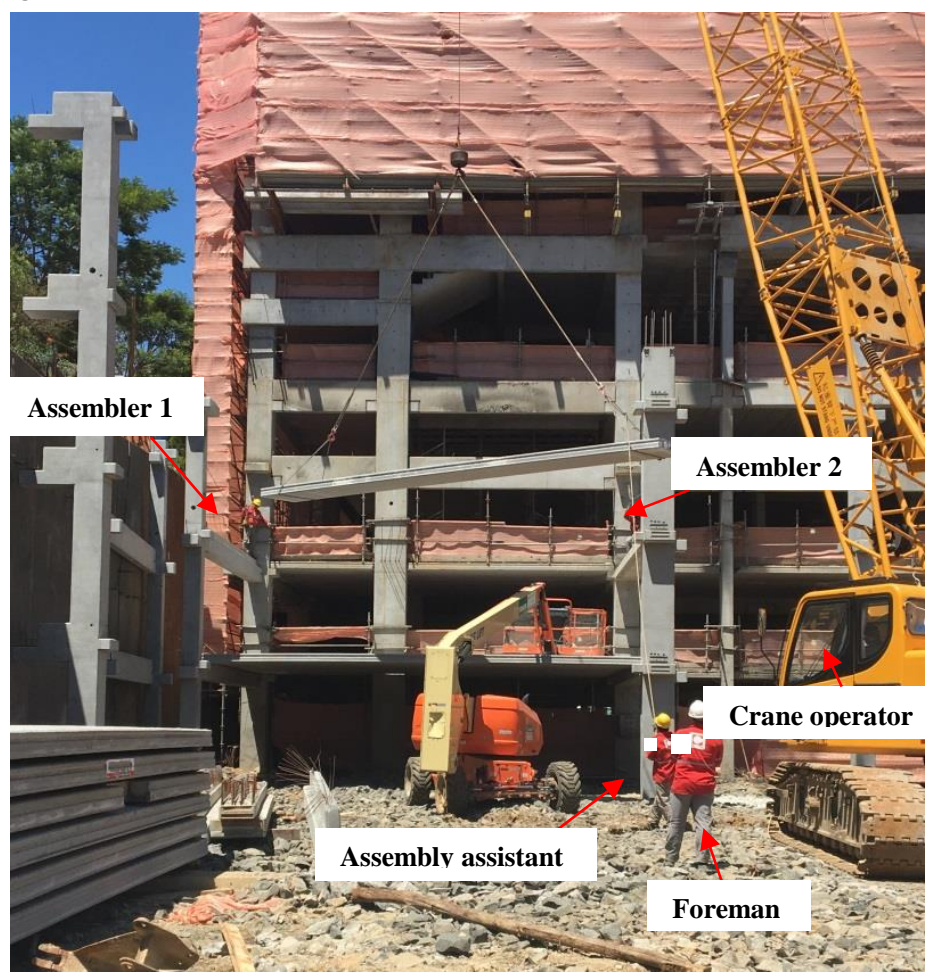


Figure 14 - Interference between two building methods: precast and concrete

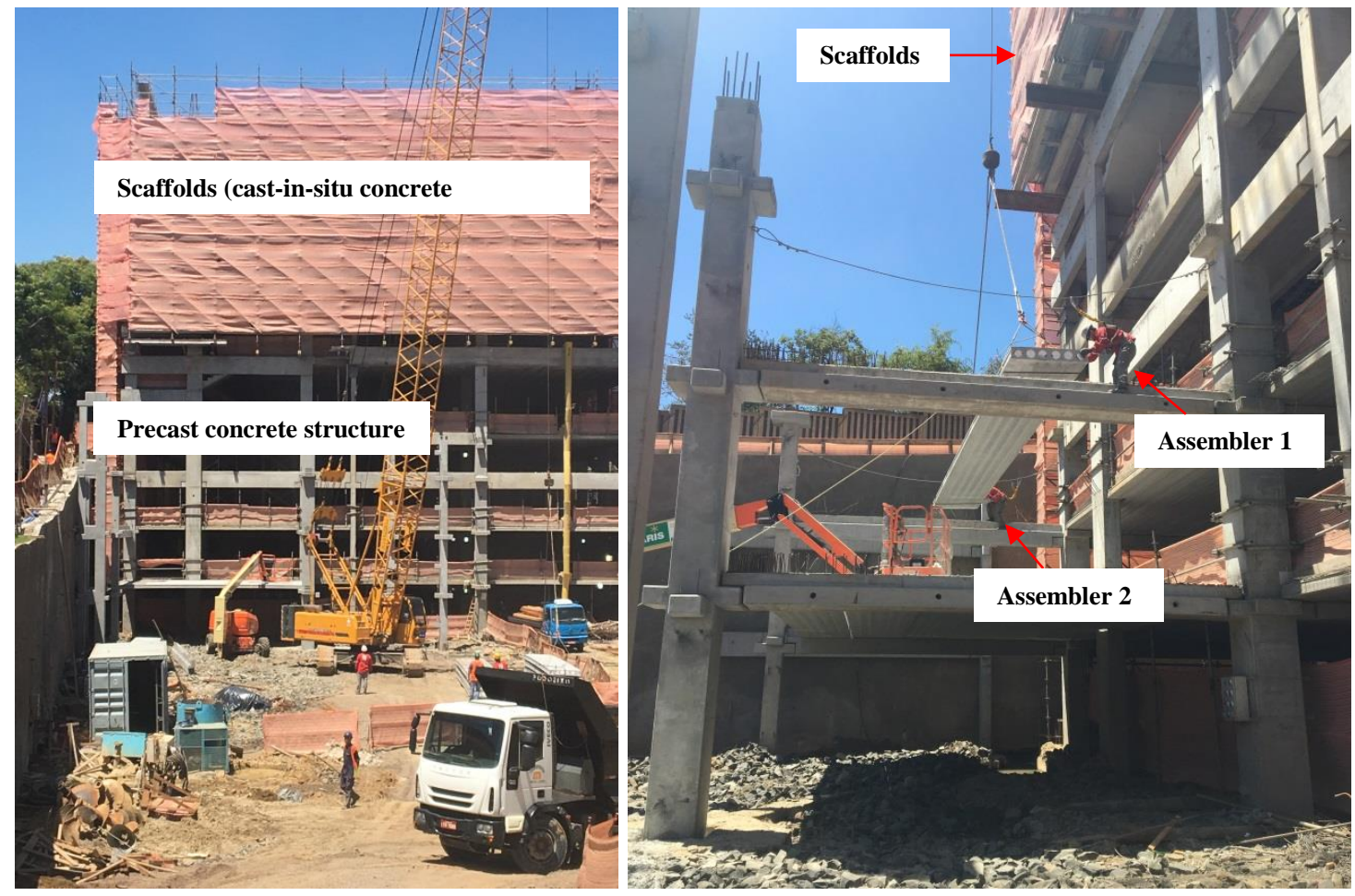

Figure 15 - Assembly of slabs: (a) Difference between the length of the slab and the one specified in label; (b) Assembler adapting the slab to the specified length

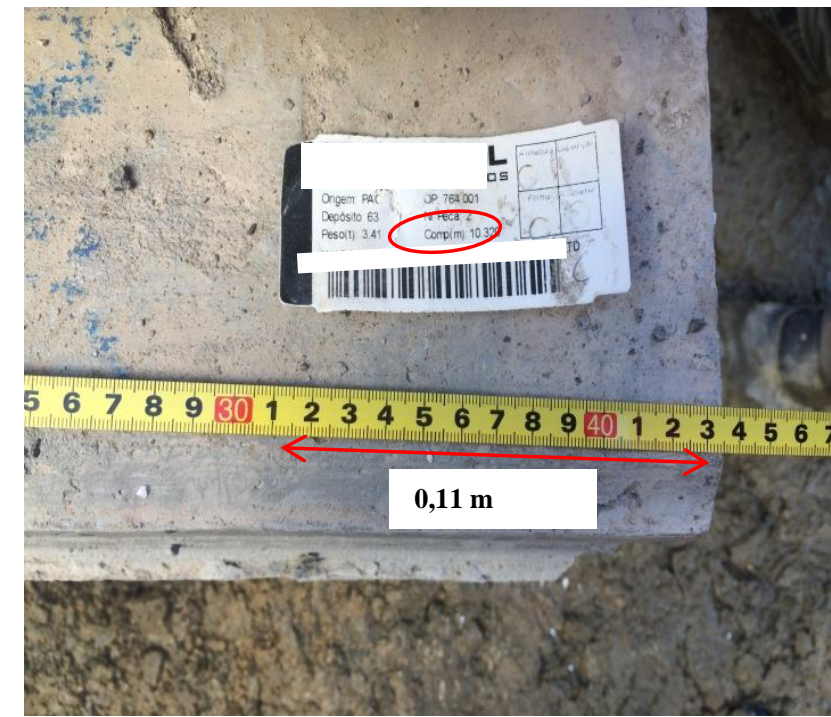

(a)

\section{Undertake specific training for developing resilience skills}

If the risks and constraints of a particular situation cannot be eliminated, the organization must ensure that those performing critical operations have appropriate skills, physical resources and respond appropriately to emergencies or unanticipated events. Indeed, specific training programs for dealing with critical process should be continuous

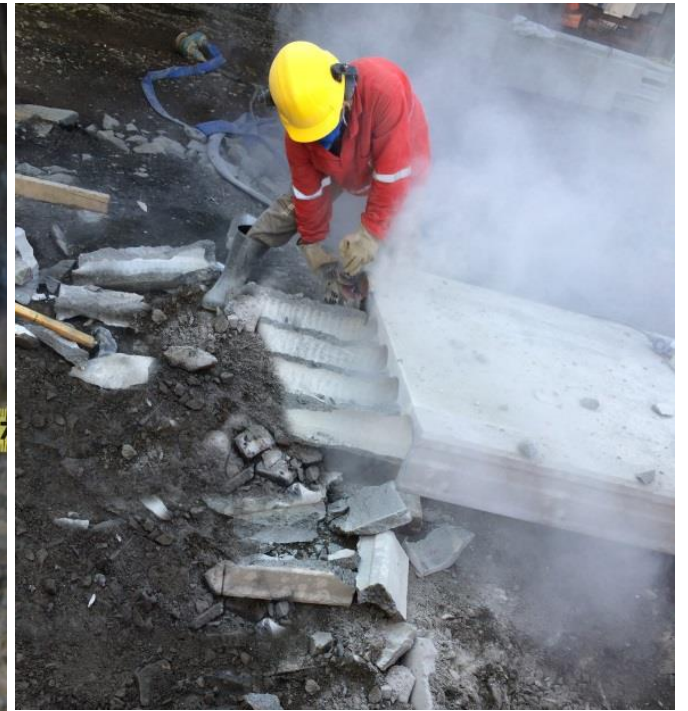

(b)

and the lessons learned, work constraints and recent events should be used as a source for updating those programs. Also, training initiatives should include different combinations of scenarios and events, such as interferences with other structures or equipment and changes in the assembly sequence, so that the assembly team are prepared to think flexibly in decision making, working as a team when necessary. 


\section{Redesign and update procedures based on the experiential knowledge of site assemblers}

By understanding the way in which the characteristics of the task being performed influence human behavior, procedures must be redesigned and updated, by considering the experiential knowledge of site assemblers. According to Hollnagel and Woods (1999), Resilience Engineering considers that designers should have an image of the cognitive performance of users of products and processes, not just a physical and physiological image of them. For instance, as mentioned above, the column assembly procedure was designed to prevent work at height, but due design and quality problems the assembly team assembler has been exposed to the risk of falls. Thus, if the risk cannot be avoided, as shown in Figure 11, experienced assemblers could devise procedures and provide training by demonstrating how to proceed in this kind of situation. In this sense, the feedback from critical process can be used to update training programs and to change standard operations or emergency procedures, as actual behaviors may differ from the prescribed procedures. In addition, procedures and training also should reflect the performance of the assemblers working under time or productivity pressures.

\section{Conclusion}

The case study carried out in this investigation provided evidences that experienced workers were able to carry out competent actions in the work environment, as a way of overcoming unexpected situations. Four categories of resilience skills were identified in this situation:

(a) compensate, by discussing set of precise maneuvers in order to reduce risk exposure;

(b) create conditions, by adopting strategies to cope with simple rework;

(c) avoid any rework that brings much uncertainty; and

(d) compensate, by assigning an experienced assembler to work at height.

Therefore, this investigation shows clearly that resilience skills have a considerable influence in the performance of the assembly team, and in the final safety outcomes.

Based on those four categories of resilience skills, three guidelines to design preventive measures, based on the Resilience Engineering perspective were proposed: (a) identify and analyze the context specific risks of each project in construction sites in order to reduce or eliminate local constraints;

(b) establish specific training for critical process to develop key resilience skills (e.g. create conditions, compensate or avoid) and update training programs as events occur; and

(c) redesign and update procedures based on the experiential knowledge of site assemblers.

Those guidelines address a gap in the literature related to the suitably skills in the context of assembling precast concrete building systems, as well as complement the current preventive measures adopted by the company.

Based on the findings of this research work, some suggestions for further studies can be made:

(a) investigate the necessary resilience skills for other critical processes in the context of precast concrete building systems, such as assembly of cladding panels or volumetric components;

(b) compare different prefabricated building systems in in terms of the necessary resilience skills; and

(c) investigate the impact of the complexity of construction projects on the emergence of organizational resilience and how it could be supported.

\section{References}

\section{AMERICAN NATIONAL STANDARDS}

INSTITUTE. ANSI A10.9: safety requirements for concrete \& masonry work. 2013. Available in: $<$ http://www.asse.org/assets/1/7/A10-9-TechBrief7-2013.pdf $>$. Access in: 15 Jan. 2016.

ASSOCIAÇÃO BRASILEIRA DE NORMAS TÉCNICAS. NBR 9062: projeto e execução de estruturas de concreto pré-moldado. Rio de Janeiro: ABNT, 2017.

BECKER, P. E.; FULLEN, M. D.; TAKACS, B. Safety Hazards to Workers in Modular Home Construction. Silver Spring. The Center toProtectWorkers' Rights. 2003.

CAMBRAIA, F. B.; SAURIN, T. A.; FORMOSO, C. T. Planejamento e Controle Integrado Entre Segurança e Produção em Processos Críticos na Construção Civil. Revista Produção, v. 18, n. 3, p. 479-492, 2008.

CODE OF PRACTICE FOR PRECAST CONCRETE CONSTRUCTION. The Buildings

Department. Hong Kong, 2016. 
CUNHA, A. Manual de Controle de Qualidade de Construções Pré-Fabricadas. Lisboa, 2011. Dissertação (Mestrado em Engenharia de Produção) - Instituto Superior Técnico, Universidade Técnica de Lisboa, 2011.

DEKKER , S. The Field Guide to Understanding Human Error. London: Ashgate, 2006.

DEKKER, S. et al. Resilience Engineering: new directions for measuring and maintaining safety in complex systems. Lund University Schoolof Aviation, 2008.

DIAS, L. M.; FONSECA, M. S. Plano de Segurança e de Saúde na Construção. Lisboa: Instituto de Desenvolvimento e Inspeção das Condições de Trabalho, 1996.

FARD, M. et al. Safety Concerns Related to Modular/Prefabricated Building construction. International Journal of Injury Control and Safety Promotion, v. 24, n. 1, p. 10-23, 2017.

FLETCHER, G. et al. The Role of Non-Technical Skills in Anesthesia: a review of current literature. British Journal of Anesthesia, v. 88, n. 3, p. 418429, 2002.

GAMBATESE, J.; HINZE, J.; HAAS, C. Tool to Design for Construction Worker Safety. Journal of Architectural Engineering, v. 3, n. 1, p. 32-41, 1997.

GIBB, A. Off-Site Fabrication: prefabrication, pre-assembly and modularization. New York: John Wiley \& Sons, 1999.

GIBB, A. et al. The Role of Design in Accident Causality. In: DESIGNING FOR SAFETY AND HEALTH IN CONSTRUCTION: RESEARCH AND PRACTICE SYMPOSIUM, Eugene, 2004. Proceedings... Eugene, 2004.

GIBB, A; ISACK, F. Re-Engineering Through Pre-Assembly: client expectations and drivers. Building Research \& Information, v. 31, n. 2, p. 146-160, 2003.

HELMREICH, RL. On Error Management: lessons from aviation. BMJ, Austin, v. 320, p. 781-785, 2000

HOLLNAGEL, E. Prologue: the scope of resilience engineering. In: HOLLNAGEL, E.; PARIÈS, J.; WOODS, D. D.; WREATHALL, J. (Eds.). Resilience Engineering in Practice: a guidebook (Resilience Engineering Perspectives Volume 3). Farnham: Ashgate, 2011.

HOLLNAGEL, E. Risk + Barriers = Safety? Safety Science, v. 46, n. 2, p. 221-229, 2008.
HOLLNAGEL, E. Safety-I and Safety-II: the past and future of safety management. Farnham: Ashgate, 2014.

HOLLNAGEL, E.; WOODS, D. D.; LEVESON, N. Resilience Engineering: concepts and precepts. Aldershot: Ashgate, 2006.

HOLLNAGEL, E.; WOODS, D. D. Cognitive Systems Engineering: new wine in new bottles. International Journal of Human-Computer Studies, v. 51, p. 339-356, 1999.

KIRUBAKARAN, C. The Masterbuilder Precast Construction: risk management. Available in: <https://www.masterbuilder.co.in/data/edata/Articl es/June2015/84.pdf>. Access in: 15 Jan. 2017.

LEVESON, N. Engineering a Safer World: systems thinking applied to safety. MIT press, 2011.

MACCHI, L. A. Resilience Engineering Approach for the Evaluation of Performance Variability: development and application of the Functional Resonance Analysis Method for air traffic management safety assessment. Thesis École Nationale Supérieuredes Mines de Paris, Paris, 2010.

MCGRAW HILL CONSTRUCTION. Safety Management in the Construction Industry: Identifying risks and reducing accidents to improve site productivity and project ROI. Bedford: McGraw Hill Construction, 2013.

MODULAR BUILDING INSTITUTE. Modular construction: a safe alternative to stick built. 2014. Available in:

<http://www.modular.org/HtmlPage.aspx?nameD Modular_A_Safe_Alternative>. Access in: 15 Dec. 2016.

NEALE, R.; SHER, W.; PRICE, A.Prefabricated Modules in Construction. Ascot: Chartered Institute of Building, 1993.

NEMETH, C. P.; HERRERA, I. Building Change: resilience engineering after ten years. Reliability Engineering System Safety, v. 141, p. 1-4, 2015.

OCCUPATIONAL SAFETY \& HEALTH ADMINISTRATION. United States Department of Labour. 1926.704: requirements for precast concrete. 1989. Available in:

<https://www.osha.gov/pls/oshaweb/owadisp.show _document?p_table $=$ STANDARDS\&p_id $=10782$

$>$ Access in: 15 Dec. 2016. 
OCCUPATIONAL SAFETY AND HEALTH SERVICE. Approved Code of Practice for the safe Handling, Transportation and Erection of Pre-Cast Concrete. Department of Labour. New Zeland, 2002.

PINTO, A. Manual de Segurança na Construção Civil. Lisboa: Edições Silabo, 2004.

POLAT, G. Factors Affecting the Use of Precast Concrete Systems in the United States. Journal of Construction Engineering and Management, v. 134, n. 3, p. 169-178, 2008.

RIBEIRO, R. Tabuleiros Pré-Fabricados vs in situ em Matéria de SST. Revista Segurança, v. 205, p. 55-56, 2011.

SAURIN, T. A. Segurança e Produção: um modelo para o planejamento e controle integrado. Porto Alegre. 2002. Tese (Doutorado em Engenharia de Produção) - Programa de PósGraduação em Engenharia de Produção, Universidade Federal do Rio Grande do Sul, Porto Alegre, 2002.
SAURIN, T. et al. The Design of Scenario-Based Training From the Resilience Engineering Perspective: a study with grid electricians. Accident Analysis \& Prevention, v. 68, p. 30-41, 2014.

TOOLE, T. M.; HERVOL, N.; HALLOWELL, M. Designing for Construction Safety. Modern Steel Construction, v. 46, p. 55-59, 2006.

WACHS, P. et al. Resilience skills as emergent phenomena: a study of emergency departments in Brazil and the United States. Applied ergonomics, v. 56, p. 227-237, 2016.

YIN, R. K. Case Study Research: design and methods. Sage publications, 2013.

\section{Acknowledgments}

This research study was developed as part of the research project entitled "Technologies for Sustainable Construction Sites in Social Housing" (CANTEC-HIS), which was carried out by four universities (UFSCar, UFRGS, UFBA and USP). We would like to thank FINEP (Financiadora de Estudos e Projetos) for funding that project.

Guillermina Andrea Peñaloza

Núcleo Orientado para Inovação da Edificação | Universidade Federal do Rio Grande do Sul | Av. Osvaldo Aranha, 99, $3^{\circ}$ Andar, Centro | Porto Alegre - RS - Brasil | Tel.: (51) 3308-3518 | E-mail: arq.guillerminapenaloza@gmail.com

\section{Carlos Torres Formoso}

Programa de Pós-Graduação em Engenharia Civil: Construção e Infraestrutura | Universidade Federal do Rio Grande do Sul |

E-mail: formoso@ufrgs.br

Tarcisio Abreu Saurin

Programa de Pós-Graduação em Engenharia Civil: Construção e Infraestrutura | Universidade Federal do Rio Grande do Sul | Tel.: (51) 3308-4299 | E-mail: saurin@ufrgs.br

Revista Ambiente Construído

Associação Nacional de Tecnologia do Ambiente Construído

Av. Osvaldo Aranha, $99-3^{\circ}$ andar, Centro

Porto Alegre - RS - Brasil

CEP $90035-190$

Telefone: +55 (51) 3308-4084

Fax: +55 (51) 3308-4054

www.seer.ufrgs.br/ambienteconstruido

E-mail: ambienteconstruido@ufrgs.br 